\title{
Uterine Corpus Myxoid Leiomyoma
}

National Cancer Institute

\section{Source}

National Cancer Institute. Uterine Corpus Myxoid Leiomyoma. NCI Thesaurus. Code C40166.

A morphologic variant of uterine corpus leiomyoma characterized by extensive myxoid degeneration of the neoplasm connective tissue stroma. 